\title{
Accuracy of the defining characteristics in nursing diagnoses of Hyperthermia in newborns
}

Acurácia das características definidoras do diagnóstico de enfermagem Hipertermia em recém-nascidos

Precisión de las características definidoras del diagnóstico de enfermería Hipertermia en recién nascidos

\section{Wislla Ketlly Menezes de Aquino', Marcos Venícios de Oliveira Lopes', Viviane Martins da Silva", Nathaly Bianka Moraes Fróes', Angélica Paixão de Menezes"II, Aline de Aquino Peres Almeida"I", Bianca Alves Sobreira"'I}

' Universidade Federal do Ceará, Postgraduate Program in Nursing. Fortaleza, Ceará, Brazil.

"Universidade Federal do Ceará, Health Sciences Center, Department of Nursing. Fortaleza, Ceará, Brazil.

"I' Universidade Federal do Ceará, Graduate in Nursing. Fortaleza, Ceará, Brazil.

How to cite this article:

Aquino WKM, Lopes MVO, Silva VM, Fróes NBM, Menezes AP, Almeida AAP, et al. Accuracy of the defining characteristics in nursing diagnoses of Hyperthermia in newborns. Rev Bras Enferm [Internet]. 2018;71(2):357-62. DOI: http://dx.doi.org/10.1590/0034-7167-2017-0037

Submission: $02-24-2017$

Approval: 04-30-2017

\begin{abstract}
Objective: to clinically validate the accuracy of the defining characteristics in nursing diagnoses of Hyperthermia in newborns. Method: a cross-sectional study conducted in units of medium and high risk in a maternity from the city of Fortaleza-CE. A total of 216 newborns were evaluated to identify the defining characteristics of diagnoses. A latent class model with random effects was used to measure sensitivity and specificity. Results: Hyperthermia was present in $5.6 \%$ of the sample. The characteristics lack of suction maintenance $(31.3 \%)$; skin warm to touch $(25.5 \%)$; lethargy $(24.2 \%)$; and tachypnea $(21.4 \%)$ were the most frequent. Stupor presented higher sensitivity $(99.9 \%)$ and specificity $(100 \%)$ while vasodilation characteristics, irritability and lethargy only showed significant values for specificity $(92.7 \%, 91.6 \%$ and $74.3 \%$, respectively). Conclusion: four characteristics of high specificity contribute to Hyperthemia. However, stupor is the only one with significant sensitivity to identify it at its early-stage. Descriptors: Nursing Diagnosis; Hyperthermia; Newborn; Control of Body Temperature; Neonatology.
\end{abstract}

\section{RESUMO}

Objetivo: validar clinicamente as características definidoras do diagnóstico de enfermagem, Hipertermia em recém-nascidos. Método: estudo transversal, realizado em unidades de médio e alto risco de uma maternidade localizada na cidade de Fortaleza-CE. Foram avaliados 216 recém-nascidos para a identificação das características definidoras do diagnóstico em estudo. Um modelo de classe latente com efeitos randômicos foi utilizado para estabelecer medidas de sensibilidade e especificidade. Resultados: a Hipertermia esteve presente em 5,6\% da amostra. As características Não manutenção da sucção $(31,3 \%)$; Pele quente ao toque (25,5\%); Letargia $(24,2 \%)$; e Taquipneia $(21,4 \%)$ foram mais frequentes. A característica estupor apresentou maior sensibilidade $(99,9 \%)$ e especificidade $(100 \%)$, enquanto as características vasodilatação, irritabilidade e letargia, apresentaram apenas valores de especificidade significativos, respectivamente $92,7 \%, 91,6 \%$ e $74,3 \%$. Conclusão: a Hipertermia está relacionada à presença das quatro características com alta especificidade, entretanto, a característica estupor foi a única com sensibilidade significativa para identificação do diagnóstico em estágio inicial.

Descritores: Diagnóstico de Enfermagem; Hipertermia; Recém-Nascido; Regulação da Temperatura Corporal; Neonatologia.

\section{RESUMEN}

Objetivo: validar clínicamente las características definidoras del diagnóstico de enfermería, Hipertermia en recién nascidos. Método: estudio transversal, realizado en las unidades de medio y alto riesgo de una maternidad ubicada en la ciudad de FortalezaCE. Fueron evaluados 216 recién nascidos para la identificación de las características definidoras del diagnóstico en estudio. Un modelo de clase latente con efectos aleatorios fue utilizado para establecer las medidas de sensibilidad y especificidad. Resultados: 
La Hipertermia estuvo presente en el 5,6\% de la prueba. Las características en el Mantenimiento de la succión (el 31,3\%); la Piel caliente al toque (el 25,5\%); la Letargia (el 24,2\%); y la Taquipnea (el 21,4\%) fueron más frecuentes. La característica estupor presentó la mayor sensibilidad (el 99,9\%) y la especificidad (el 100\%), mientras que las características vasodilatación, irritabilidad y letargia, presentaron solamente los valores de especificidad significativos, respectivamente el 92,7\%, el 91,6\% y el 74,3\%. Conclusión: La Hipertermia está relacionada a la presencia de las cuatro características con alta especificidad, mientras tanto, la característica estupor fue la única con sensibilidad significativa para identificación del diagnóstico en etapa inicial.

Descriptores: Diagnóstico de Enfermería; Hipertermia; Recién Nascido; Regulación de la Temperatura Corporal; Neonatología.

\section{CORRESPONDING AUTHOR Wislla Ketlly Menezes de Aquino E-mail: wislla.aquino@hotmail.com}

\section{INTRODUCTION}

In newborns (NB), heat losses are generally higher than its production, especially among Preterm Newborns (PNB) of low weight at birth ${ }^{(1)}$. However, studies also show that exposure to hot environments (inadequate clothing for room temperature, phototherapeutic treatment, radiant heat cots and/or neonatal incubators when not regularly adjusted) contribute to increased temperatures both in the body of term (TNB) and preterm newborns (PNB) ${ }^{(2-3)}$.

Neonatal hyperthermia deserves attention because the brain is a quite sensitive organ to thermal changes. Mechanisms possibly associated with this effect include the liberation of free radicals and excitatory neurotransmitters that cause epilepsy. Despite the fact that most patients with high temperature had fever, increases in body temperature can have another reason, i.e., increases in the environment temperature can affect the newborn's body temperature, thus being considered hyperthermia. Fever is a nosological entity characterized as a syndrome caused by inflammatory symptoms, while hyperthermia does not comprise pyrogenic molecules and has a thermoregulatory center that remains unchanged. Besides clinical history, some physical signs can indicate hyperthermia such as warm and dry skin $^{(4-5)}$. When caused by dehydration, usually it was also possible to note weight loss and inadequate suction ${ }^{(6)}$.

We can highlight important differences between thermal changes caused by the environment and the ones caused by infections. In fever, there is an increase in core temperature with subsequent increase in skin temperature. This is because bacteria or endotoxins have the ability to raise the set point of the hypothalamic center. Under these circumstances, we adjusted the temperature to a value higher than the standards $\left(36.5^{\circ} \mathrm{C}\right.$ to $37^{\circ} \mathrm{C}$ in NB) such as $39^{\circ} \mathrm{C}$. During fever, vasoconstriction can occur as an attempt to conserve heat, contributing to the emergence of cold extremities, dark or pale spots and differences of up to $3^{\circ} \mathrm{C}$ between the temperatures measured in different body regions $^{(7-8)}$.

On the other hand, hyperthermia starts with an increase in skin temperature followed by an increase in core temperature. Which is because of the skin-air temperature range; when the air temperature is higher than the temperature of the skin, the NB absorbs heat by convection. The NB can get angry and anxious and/or stand in a flaccid position to increase heat transfer from the skin to the environment, which can lead to vasodilation and vasoconstriction as it occurs in fever ${ }^{(8)}$.

NANDA International (NANDA-I) ${ }^{(9)}$ taxonomy included hyperthermia as part of the nursing diagnosis by 1986 and reviewed its structure by 2013. In the last review, we added new defining characteristics and changed the definition to "body temperature above the daytime standards because of thermoregulatory failure." The latest edition of NANDA-I taxonomy includes 15 defining characteristics, nine of them being added (abnormal posture, apnea, coma, irritability, lethargy, stupor, hypotension, vasodilatation and lack of suction maintenance) and six remaining from the previous version (epilepsy, epilepsy crises, flushing, skin warm to the touch, tachycardia and tachypnea).

Despite being reviewed, there is still no knowledge on which defining characteristics are more accurate to diagnose hyperthermia. The accuracy of the defining characteristics is a way of clinically validating nursing diagnoses based on sensitivity and specificity measures and of classifying individuals with and without a nursing diagnosis ${ }^{(10-11)}$.

In this context, the early detection of thermal imbalance depends on the nurse's knowledge on the characteristics that define accuracy. As any technology, the measurement equipment can fail, thus we cannot consider the temperature value exclusively. In addition, nursing actions must be taken based on the patient's clinical signs that allow the continuous validation of nursing results ${ }^{(12)}$. This study aims to clinically validate the defining characteristics of diagnoses of Hyperthermia in newborns.

\section{METHOD}

\section{Ethical aspects}

The institution's Research Ethics Committee approved this study. Parents/legal guardians have signed an informed consent form before data collection.

\section{Design, local of study and period}

This is a cross-sectional study on the accuracy of the defining characteristics of nursing diagnoses of Hyperthermia developed in neonatal units of medium and high risk of a maternity from Fortaleza-CE, from October 2015 to March 2016.

\section{Sample and inclusion and exclusion criteria}

The sample comprised 216 NB, including the ones aged up to seven days, who were consecutively sampled after their admission. Newborns that were hemodynamically unstable and/ or with fever caused by infections were excluded. According to the measurements recommendations to study diagnosis accuracy, the initial estimate of the sample was obtained considering 15 subjects to each evaluated characteristic (14), totaling 210 participants ${ }^{(13)}$. However, a final sample of 216 was obtained because of the increased availability of NB during data collection. 


\section{Study protocol}

The instrument used for data collection comprised a threepart form: 1. Clinical data (birth conditions, delivery, gestational age, post birth age and weight); 2. Physical exam organized in organic systems to identify the defining characteristics; 3. Standard operating procedure (SOP) containing the conceptual and operational definitions of the measured defining characteristics. Conceptual and operational definitions were created from the query of articles and textbooks of Physiology, Semiology and Neonatology.

The construction of the instrument was conducted followed by an integrative review aiming at investigating the literature and the description of signs and symptoms from hyperthermia that were still not part of defining characteristics of NANDA I for this diagnosis. After the review, there were only signs for hypotonia, which was later added to the SOP. The instrument was subjected to the evaluation of the members of a research group on nursing diagnoses regarding children's health. The definitions of the defining characteristics were presented and some comments on their clarity and applicability were made by participants, the ones considered relevant being adopted by us.

Although the defining characteristics, convulsions and convulsive seizures have different conceptual definitions, the operation methods of evaluation are the same. Then, we decided to use only the term convulsive seizures. Hypotension was evaluated in NB in units of medium complexity because of limitations regarding the auscultatory and palpatory measurement methods, both considered unreliable due to the size of the children's arms and the difficulty in listening to the Korotkoff sounds caused by the low frequency and amplitude of the pulses ${ }^{(14)}$. On the other hand, it was possible to measure the blood pressure of NB hospitalized in units of high risk, because they were being electronic monitored.

Data were collected by a previously trained team that comprised nurses from a research group on nursing diagnosis, as recommended by specialists ${ }^{(11)}$ of diagnosis accuracy. To standardize data collection, all participants of the data collection team strictly followed the operational definitions included in the SOP of the defining characteristics under evaluation.

\section{Statistical analysis}

Data were analyzed by statistical package $R$ version 3.1.1. The descriptive analysis of the data comprised measures of absolute frequencies, percentages, and measures of central tendency and dispersion. In addition, confidence intervals of $95 \%$ were calculated proportionally to categorical variables. The Lilliefors test was applied to observe adherence at normal distribution. The association between the defining characteristics and the clinical variables of NB was analyzed using the Chi-square test and/or Fisher's exact test according to the frequencies of each category. To measure the extent of the relation between the defining characteristics and the categorical variables of interest, Odds Ratio (OR) with a confidence interval of $95 \%$ was used. Weight and the presence of some of the defining characteristics were evaluated by applying the Mann-Whitney nonparametric test.

To verify sensitivity (proportion of subjects with nursing diagnosis for which the indicator is present) and specificity (proportion of subjects without diagnosis for which the indicator is absent) of each defining characteristic, the latent class analysis (LCA) method was used based on the model of random effects. A model of two latent classes with random effects was used to measure sensitivity and specificity values with confidence intervals of $95 \%$. The model of randomized effects implies a conditional dependency between the defining characteristics of the diagnosis under analysis. Thus, this approach implies that a latent variable (nursing diagnosis) determines the associations between the directly observable variables (defining characteristics). From these relations, the measures of diagnosis accuracy were calculated. To verify how good the adjustment of latent class models was, a likelihood ratio test $^{(\mathrm{G} 2)}$ was applied. In this analysis, randomLCA and poLCa packages from the software $R$ were used $^{(15-16)}$.

From the model, the defining characteristics that showed no statistical significance were deleted and a new model was adjusted. The lack of statistical significance was not considered when the upper limit of the confidence interval for sensitivity and specificity was lower than $50 \%$ and/or when the confidence interval included this value.

\section{RESULTS}

In this sample, PNB (IG $\leq 37$ weeks) were the most predominant, representing $67.1 \%$ from the total. The average age was of 34.5 weeks, the average weight at data collection was of $2,152.7 \mathrm{~g}(\mathrm{DP}=887.7$ ), and $54.5 \%$ of them were male. Despite the prevalence of PNB, a small number depended on breathing support, while $63.9 \%$ remained in ambient air.

Regarding devices for heat maintenance and control, we identified that $10.6 \%$ of the sample used a warm and humid incubator. In addition, $50 \%$ of NB were in incubators without humidification, $6.5 \%$ of them were in radiant-heat cradles, $31 \%$ in common warm cradles, and $1.9 \%$ in BiliBeds. In addition to BiliBed, we applied phototherapy in $26.3 \%$ of PNB using Bilitron, considering they could not be removed from the incubators. Regarding intravenous therapy for antibiotics $(25.4 \%)$, hydration (25\%), when compared with TNB $(17.1 \%)$, PNB showed to be the most frequent.

Regarding medical diagnoses, respiratory diseases were the most frequent $(30 \%)$, followed by perinatal infections $(22 \%)$, and prematurity $(23 \%)$, while metabolic and hemodynamic disorders and congenital malformations were not as frequent ( $8 \%$ and $5 \%$, respectively). Another parcel was still under clinical observation and had no diagnosis (12\%).

Hyperthermia showed a prevalence of $5.6 \%$. Table 1 presents 13 characteristics from the 15 evaluated in the sample; we did not find coma and seizures in the sample. The most frequent defining characteristic was lack of suction maintenance $(31.3 \%)$, followed by warm skin $(25.5 \%)$, lethargy $(24.2 \%)$, and tachypnea $(21.4 \%)$. Least frequent characteristics were hypertension $(0.5 \%)$, apnea $(2.8 \%)$, stupor $(5.6 \%)$, vasodilation, abnormal posture, and irritability (7.9\%).

By analyzing the association between the defining characteristics and clinical data of this population, we identified that NB not undergoing phototherapy had a higher chance to show characteristics such as flushing, $\left(\mathrm{OR}=2.80 ; 95 \% \mathrm{Cl}: 1.03-7.58 ;^{2}=4.39\right.$; $\mathrm{gl}=1 ; \mathrm{p}=0,036)$ and lethargy $(\mathrm{OR}=2,24 ; 95 \% \mathrm{Cl}: 1.01-4.93$; 
$2=4.13 ; g \mid=1 ; p=0.042)$. Intravenous hydration increase of chance in tachypnea $\left(\mathrm{OR}=2.17 ; 95 \% \mathrm{Cl}: 1.07-4.37 ;^{2}=4.77\right.$; $\mathrm{gl}=1 ; \mathrm{p}=0.029$ ). Current weight was statistically inferior among children with these characteristics, lack of suction maintenance (average rank: 77.91 vs. 107.15; $U=2861.5 ; \mathrm{p}=0.001$ ), tachycardia (average rank: 84.52 vs. 111.50; $U=1728.5 ; p=0.046$ ) and stupor (average rank: 55.58 vs. 110.07; $U=589.0 ; p=0.003$ ). We identified no statistical relationship between the defining characteristics and the use of devices for maintenance and control of heat loss.

Table 2 presents data regarding the latent class of analysis of Hyperthermia diagnosis. After adjusting the model, there was four defining characteristics left. Stupor was the characteristic that showed the highest sensitivity value (99.9\%), which means that, when it occurs, it is likely that the patient is at the early stages of Hyperthermia. The same characteristic showed the highest value for specificity $(100 \%)$, followed by vasodilation $(92.7 \%)$, irritability $(91.6 \%)$, and lethargy $(74.3 \%)$. Therefore, the presence of these four characteristics is a strong indicative of Hyperthermia.

Table 1 - Defining characteristics of Hyperthermia diagnosis in the sample $(\mathrm{N}=216)$, Fortaleza, Ceará, Brazil, 2016

\begin{tabular}{lccc}
\hline Defining characteristics & $\mathbf{n}$ & $\mathbf{\%}$ & $\mathbf{9 5 \%} \mathbf{C l}$ \\
\hline Lack of suction maintenance & 61 & 31.3 & $24.9-38.4$ \\
Warm skin $^{1}$ & 55 & 25.5 & $19.9-31.9$ \\
Lethargy $^{1}$ & 52 & 24.2 & $18.7-30.6$ \\
Tachypnea $^{1}$ & 46 & 21.4 & $16.2-27.6$ \\
Flushing $_{\text {Hypotonia }}$ & 36 & 16.7 & $12.1-22.5$ \\
Tachycardia $_{\text {Irritability }}{ }^{1}$ & 36 & 16.7 & $12.1-22.5$ \\
Abnormal posture & 24 & 11.1 & $7.4-16.3$ \\
Vasodilation $_{\text {Stupor }}{ }^{3}$ & 17 & 7.9 & $4.8-12.6$ \\
Apnea & 17 & 7.9 & $4.8-12.6$ \\
Hypotension $^{2}$ & 17 & 7.9 & $4.8-12.5$ \\
\hline
\end{tabular}

Note: ${ }^{1} n=215 ;{ }^{2} n=214 ;{ }^{3} n=213 ; 95 \% \mathrm{Cl}: 95 \%$ of confidence interval

\section{DISCUSSION}

The health team is always concerned with prevention of hypothermia, this way some of the measures taken to reverse hypothermia can cause hyperthermia by excess of heat. In our study, we observed the use of blankets, boots and gloves with NB in medium risk units who were in warm cradles because they were more exposed to the air-conditioning of the neonatal unit. This is important because warm cradles, when compared with incubators, do not provide a neutral thermal environment capable of ensuring a minimum metabolic expenditure and a stable body temperature ${ }^{(8)}$. However, using these protection measures in excess is a common cause of hyperthermia because of the newborn's difficulty in dissipating heat ${ }^{(3)}$.

Regarding the influences of technology, the literature describes that NB undergoing phototherapy are exposed to several changes, such as diarrhea; increases in water loss, which, when added to the period of breastfeeding adjustment can lead to dehydration; susceptibility to Hyperthermia and Hypothermia due to direct exposure to heat (light) or lack of heating in the normal crib or Bilitron; as well as the darkening of the skin, called Bronze Baby Syndrome ${ }^{(17)}$. Differently from the expected, none of the defining characteristics showed association with phototherapy. Newborns that were not undergoing phototherapy had a higher chance of presenting flushing and lethargy, both part of the Hyperthermia diagnosis.

It is possible that these divergent results are associated with technological change. Currently, neonatal units have modern phototherapy equipment, such as the LED light emitting $\mathrm{Bi}$ litron and Bilibed. Unlike the fluorescent and incandescent lamps previously used, in LED lamps, most of the energy is in the visible spectrum of light and does not generate heat.

Interestingly, tachypnea showed association with the use of intravenous hydration. The use of intravenous hydration is common among NB that are still not capable of eating, as it restores the losses and meets the required amount of calories to increase body mass. This treatment is for newborns $<1,500 \mathrm{~g}$ who are unable to eat, present breathing discomfort, necrotizing enterocolitis, severe asphyxia, and surgical pathologies ${ }^{(18)}$. It is likely that intravenous hydration has showed association with tachypnea, not for being a risk factor for Hyperthermia, but for its indication being more frequent among NB predisposed to breathing stress.

Regarding the diagnosis in Hyperthermia, the characteristics that showed higher frequency were: lack of suction maintenance $(31.3 \%)$, followed by skin warm to the touch $(25.5 \%)$, lethargy (24.2\%), and tachypnea (21.4\%). Braga et al. (2013) found similar results, warm skin being the most frequent characteristic $(58.7 \%)$, followed by lethargy $(45.7 \%)$ in the diagnosis of Hyperthermia. The low frequencies of the characteristics identified in our study influenced the latent class model for hyperthermia, which ended up including only four characteristics and determining a low prevalence of diagnosis in the studied sample. Although it has been identified a wide range of characteristics

Note: Se: sensitivity; Sp: Specificity; 95\% Cl. Confidence interval of 95\%; G2 likelihood ratio; DF: Degrees of freedom 
(a total of 13), their low frequencies reduced the likelihood of association between them, thus establishing a latent class model with adequate adjustment.

Regarding the sensitivity and specificity measures, stupor was the one that showed the best sensitivity and specificity value, while vasodilation, irritability, and lethargy only showed significant values for specificity. According to these data, studies on the effects of Hyperthermia in newborns highlight the presence of vasodilation, stupor, lethargy and irritability as important signs of the body undergoing Hyperthermia ${ }^{(8,19,3)}$. Some of these responses are an attempt to dissipate heat. Considering newborns have a reduced ability to sweat, they need vasodilation to help them conduct warm blood to the skin and dissipate more heat ${ }^{(20)}$.

Regarding behavior changes, the child can become angry and anxious and stand in a flaccid posture to increase the dissipation of heat from the skin to the environment ${ }^{(21)}$. The posture response of the new born to hyperthermia is the extension of arms and legs, the reduction in spontaneous activity and the increase in the duration of sleep, in an attempt to dissipate as much heat as possible $\mathrm{e}^{(22)}$.

Despite abnormal posture being a lot present in the literature, in the data of this research, it only had a frequency of $6.7 \%$; hypotonia, on the other hand, had a frequency of $16.7 \%$. This is due to the fact that it is not possible to measure abnormal posture in all newborns, considering the normal flexed position is not common among PNB, because their flexor tone will only be fully developed by the 32 nd gestational week. In addition, extreme premature newborns do not have the ability to change their posture during the first week of life; only $30 \%$ of newborns above 30 weeks are able to extend their members. After two weeks, this number increases to $87 \%$. Thus, in the first week of life, PNB are more vulnerable to thermal instability, because they cannot modify their body position yet to contribute to heat dissipation or conservation ${ }^{(22)}$.

\section{Study limitations}

Limitations found in this study concerned the aspects of the population under study. In this sample, the highest frequency was for PNB in this particular group. Because of its anatomophysiological immaturity, several defining characteristics can be absent, despite the increasing temperatures, which explains the low frequencies among the defining characteristics of this study. In addition, it was not possible to evaluate hypotention among NB hospitalized in units of medium complexity because these units did not carry out the electronic monitoring of blood pressure, considering its verification is not common among stable NB. Defining characteristics such as hypotension, abnormal posture, lack of suction maintenance, vasodilation, and skin warm to touch were difficult to measure because they depended on the newborn's maturation, so we might have underestimated them. It is worth highlighting the defining characteristics that showed significant sensitivity and specificity measures were only valid for NB aged up to seven days.

\section{Contributions to the health field}

The sensitivity and specificity measures of the found defining characteristics can add useful information to the process of diagnosis of Hyperthermia in NB. Considering the complexity of a nursing diagnosis, we hope the evidences from this study contribute to discussions and investigations on the matter and also to the evaluation of this diagnosis in clinical practice.

\section{CONCLUSION}

The sensitivity and specificity measures of the found defining characteristics can add useful information to the process of diagnosis of Hyperthermia in NB. We were able to evaluate the profile of hospitalized NB in units of medium and high complexity. We identified that stupor showed the highest sensitivity value, which means that, at its presence, the patient's might have been going through the early stages of Hyperthermia. The characteristics with high specificity values were: stupor, vasodilation, irritability and lethargy, therefore, the four of them are important to confirm the presence of Hyperthermia. On the other hand, stupor proved to be useful both for confirmation and for early diagnosis.

Considering the frequencies of the defining characteristics were low, the results must be used with caution. The literature highlights that both frequencies and accuracy measures can be influenced by the hyperthermia, which means they can be higher with the worsening of clinical conditions. Unfortunately, the lack of studies with similar methodology limited the comparison of the results of this study.

This way, there is need for future studies with larger samples to find more serious spectra of the phenomena investigated and compare the serious and light spectra to be able to state with higher precision if these defining characteristics represent the diagnosis of Hyperthermia in this population.

\section{FUNDING}

The authors declare to have received funding from the Coordination of Improvement of Higher Level Personnel (Coordenação de Aperfeiçoamento de Pessoal de Nível SuperiorCAPES), Brazil.

\section{REFERENCES}

1. Laptook AR, Salhab W, Bhaskar B. Admission temperature of low birth weight infants: predictors and associated morbidities. Pediatrics [Internet]. 2007 [cited 2016 Nov 14];119(3):643-49. Available from: https://www.ncbi.nlm.nih.gov/pubmed/17296783

2. Inácio CCN, Chaves EMC, Freitas MC, Siebra e Silva AV, Alves AR, Monteiro AR. Diagnósticos de enfermagem em unidades de alojamento conjunto. Rev Bras Enferm [Internet]. 2010 [cited 2016 Nov 16];63(6):894-99. Available from: http://www.scielo.br/ pdf/reben/v63n6/04.pdf 
3. Molgat-Seon Y, Daboval T, Chou S, Jay I. Accidental overheating of a newborn under an infant radiant warmer: a lesson for future use. J Perinatol [Internet]. 2013[cited 2016 Nov 10];33(1):738-9. Available from: http://www.nature.com/jp/journal/v33/n9/full/ jp201332a.html/doi:10.1038/jp.2013.32

4. Salgado PO, Silva LCR, Silva PMA, Chanca TCM. Hipertermia. In: Nanda Internacional. Herdman T H, Lopes M V O, Almeida MA Chanca TCM. (orgs.). PRONANDA. Programa de atualização em diagnóstico de enfermagem: Ciclo 2. Porto Alegre: Artmed; 2014.p.103-20.

5. Dinarello CA, Gelfand JA. Fever and hyperthermia. In: Fauci AS, Braunwald E, Kasper DL, Hauser SL, Longo DL, Jameson JL et al. Harrison's principles of internal medicine. $17^{\text {th }}$ ed. New York: Mc Graw-Hill; 2008. p.112-6.

6. Barbosa NOE, Mancini MC, Reyes AMA, Nascimento NC, Vaz FAC, Leone CR. Caracterização da hipertermia em recém-nascidos de termo. Pediatria [Internet]. 2000 [cited 2016 Nov 20];22(1):29-34. Available from: http://pesquisa.bvs.br/brasil/resource/pt/lil-279802

7. Hall JE. Guyton and Hall textbook of medical physiology. $13^{\text {th }}$ ed. Philadelphia: Elservier; 2011.

8. Altimier L. Thermoregulation: what's new? What's not? newborns and infant nursing reviews [Internet]. 2012[cited 2016 Nov 15];12(1):71320. Available from: https://www.researchgate.net/publication/272023817_Thermoregulation_What's_New_What's_Not

9. Herdman TH, Kamitsuru S. (eds.). NANDA International Nursing Diagnoses: definitions and classification, 2015-2017. Oxford: Wiley-Blackwell; 2014.

10. Zhou X, Obuchowski NA, Mcclish DK. Statistical methods in diagnostic medicine. New York: Wiley Interscience; 2002.

11. Lopes MVO, Silva VM, Araújo TL. Methods for establishing the accuracy of clinical indicators in predicting nursing diagnoses. Int J Nurs Knowl [Internet]. 2012[cited 2016 Nov 10];23(3):134-9. Available from: https://www.ncbi.nlm.nih.gov/pubmed/23043652

12. Herdman TH. Uma revisão da literatura neonatal para identificar para identificar atributos críticos para diagnósticos de enfermagem de hipotermia. Rev Rene [Internet]. 2013[cited 2016 Nov 12];14(6):1242-51. Available from: http://www.repositorio. ufc.br/handle/riufc/11372

13. Swanson SA, Lindenberg K, Bauer S, Crosby RD. Monte Carlo investigation of factors influencing latent class analysis: an application to eating disorder research. Int J Eating Disord[Internet]. 2012 [cited 2016 Nov 10];45(5):677-84. Available from: https://www.ncbi.nlm.nih.gov/pubmed/21882219

14. Ribeiro MAS, Garcia PCR, Fiori RM. Determination of blood pressure in newborns. Scientia Med[Internet]. 2014 [cited 2016 Nov 18];17(3):156-67. Available from: http://revistaseletronicas.pucrs.br/ojs/index.php/scientiamedica/article/viewFile/1665/2148

15. Beath K. Random-LCA: Random Effects Latent Class Analysis. Rpackage version 1.0-3[Internet]. 2015 [cited 2016 Nov 13 ]. Available from: http://CRAN.R-project.org/package $=$ randomLCA

16. Linzer DA, Lewis JB. poLCA: An R Package for Polytomous Variable Latent Class Analysis. J Stat Softw [Internet]. 2011 [cited 2016 Nov 13];42(10):1-29. Available from: http://www.jstatsoft.org/v42/i10/

17. Mata-Sandoval A, Villa-Guillên M, Sierra MT. Icterícia neonatal-Tratamento de la hiperbilirrubinemia no conjugada: considerações fetales y neonatales. Bol Med Hosp Infant Mex. 2000;57(3):167-75.

18. Moreira MEL, Lopes JMA, Carvalho M. O recém-nascido de alto-risco: teoria e prática do cuidar. Rio de Janeiro: Editora FIOCRUZ; 2004.

19. Braga FC, Santos ARC, Castro NB, Nunes MM, Lopes MVO, Silva VMS. Acurácia dos indicadores clínicos dos diagnósticos de Enfermagem hipertermia e hipotermia em recém-nascidos. Rev Rene [Internet]. 2014[cited 2016 Nov 21];15(5):789-95. Available from: http://www.periodicos.ufc.br/index.php/rene/article/viewFile/3243/2498

20. Bissinger RL, Annibale DJ. Thermoregulation in Very Low-Birth-Weight Infants During the Golden Hour. Adv Neonatal Care [internet]. 2010[cited 2016 Nov 20];10(5):230-8. Available from: https://www.ncbi.nlm.nih.gov/pubmed/20838071

21. Mhairi G, MacDonald MG, Seshia MMK. Avery's Neonatology: patophysiology and management of the newborn. $7^{\text {th }}$ ed. Philadelphia: Lippincott Williams \& Wilkins; 2010.

22. Fanaroff AA, Fanaroff JM. Care of the high-risk neonate. $6^{\text {th }}$ ed. Philadelphia: Saunders; 2015. 